\title{
IMPACTS OF CLIMATE CHANGE AND DEVELOPMENT ON SHOREBIRDS OF THE ARCTIC NATIONAL WILDLIFE REFUGE
}

\author{
Steve Kendall ${ }^{1}$, David Payer ${ }^{1}$, Stephen Brown ${ }^{2}$, and Roy Churchwell ${ }^{3}$ \\ ${ }^{1}$ US Fish And Wildlife Service, Arctic National Wildlife Refuge, \\ 101 12th Avenue, Fairbanks, AK 99701, USA \\ E-mail: Steve_Kendall@fws.gov \\ ${ }^{2}$ Manomet Center for Conservation Sciences, \\ P.O. Box 1770, Manomet, MA 02345, USA \\ ${ }^{3}$ Department of Biology and Wildlife, 211 Irving 1, University of Alaska, \\ Fairbanks, AK 99775, USA
}

\begin{abstract}
Impacts of climate change are amplified at high latitudes such as the Arctic Coastal Plain of Alaska. In addition, this region and adjacent offshore areas are experiencing rapid changes associated with oil and gas exploration and production. The Arctic National Wildlife Refuge's location in northeast Alaska makes it particularly vulnerable to these environmental perturbations. Recognizing this, we have implemented several collaborative investigations of at-risk bird populations and habitats since 2002. In this paper we focus on studies of shorebirds using tundra and coastal habitats. Objectives include: (1) identify important habitats for nesting and staging; (2) assess effects of development on nest predation and success rates; (3) examine post-breeding shorebird staging ecology; and (4) develop models using demographic and environmental data to evaluate causes of shorebird population declines. Evaluating impacts of changing environmental conditions on birds is an overarching objective of all studies. Initial results suggest that the impacts of development on nest success are small relative to natural variability, but could be important as additive stressors. We identified several high-use areas for post-breeding shorebirds, but also found considerable inter-annual and within-season variability in bird distribution. We are currently investigating factors associated with shorebird use of coastal habitats including availability of food resources. We recently initiated further studies on demographics of breeding shorebirds. Several years of data from multiple sites will be required to evaluate shorebird population dynamics in this highly variable and rapidly changing environment. Our studies will contribute to understanding population limitation and developing conservation actions for arctic shorebirds. Received 4 March 2011, accepted 15 April 2011.
\end{abstract}

Kendall, S., D. Payer, S. Brown, And R. Churchwell. 2011. Impacts of climate change and development on shorebirds of the Arctic National Wildlife Refuge. Pages 91-100 in R. T. Watson, T. J. Cade, M. Fuller, G. Hunt, and E. Potapov (Eds.). Gyrfalcons and Ptarmigan in a Changing World, Volume I. The Peregrine Fund, Boise, Idaho, USA. http://dx.doi.org/10.4080/gpcw.2011.0109

Key words: Arctic, shorebirds, climate change, human development. 
MANY SPECIES OF SHOREBIRDS have experienced dramatic population declines in recent decades (Brown et al. 2001, ASG 2008), the causes of which are often unknown. If current rates of decline are sustained, some of these species will become endangered in the near future. The Arctic National Wildlife Refuge (Arctic Refuge) provides important breeding and foraging habitats for several species of shorebirds. Sufficiently large numbers of shorebirds breed on the Arctic Refuge coastal plain (Brown et al. 2007) to make it eligible for designation as a wetland of international importance under the Western Hemisphere Shorebird Reserve Network (WSHRN 2006) and the Ramsar Convention (Ramsar 1999), although no such designation is yet in place. Additionally, coastal areas of the Arctic Refuge provide important foraging habitats for post breeding shorebirds. These shorebird populations face multiple environmental challenges throughout their lifecycle, including at their breeding sites. On the Arctic Refuge, climate change and human development pose potential challenges for shorebirds.

Effects of climate change are especially intense in the Arctic (ACIA 2005). In the last 100 years, the Arctic has experienced a rate of warming double that of the global average (ACIA 2005, IPCC 2007). Warming in northern Alaska and western Canada has been particularly pronounced (Martin et al. 2009). Climate change could impact Arctic habitats and wildlife in several ways, including habitat alteration and loss, trophic mismatch between predators and prey, extreme weather events, and changes in hydrology (Martin et al. 2009).

Arctic coastal areas are especially vulnerable to climate change. The total area of summer sea ice in the Arctic has decreased considerably in recent years, and the Arctic Ocean could be ice free during summer in 20 to 30 years (NSIDC 2010). Ice has receded to $>300$ $\mathrm{km}$ from the coast of Alaska in the past several summers and the duration of the ice-free period is increasing. Reduced buffering from sea ice results in increased wave energy on coastlines, and leads to storm surges and increased coastal erosion. Significant erosion in some coastal areas of the Arctic Refuge has already occurred, with up to several meters of shoreline lost in single storm events (USFWS, unpubl. data).

Another effect of warming is sea-level rise caused by melting glaciers and thermal expansion of ocean waters (IPCC 2007). Sea-level rise results in greater likelihood that storm surges will flood coastal areas, impacting wildlife dependent on this habitat. For example, the low-elevation, ephemeral barrier islands that define much of the northern border of the Arctic Refuge provide important nesting habitat for several species of birds, including Common Eider (Somateria mollissima; Kendall 2005). These sea ducks require driftwood for nesting cover, which typically accumulates on the islands. Flooding can result in redistribution or removal of driftwood, reducing habitat quality for nesting birds. Inundation of nests may also directly cause nest failure, and ultimately may result in loss of the barrier islands themselves if erosion exceeds accretion (Martin et al. 2009).

The lagoons formed between the barrier islands and the mainland are important foraging and staging habitat for many species, including Red-necked Phalaropes (Phalaropus lobatus) and Long-tailed Ducks (Clangula hyemalis). These lagoons are brackish, shallow, and biologically rich. If the islands disappear, this important habitat would be lost.

Coastal areas provide important foraging habitat for post-breeding shorebirds as they build energy reserves for southward migration. We have observed displacement of foraging birds by flooding during peak staging periods, which may have negative energetic consequences. Increased rate of occurrence or severity of flooding would likely create additional energetic stress on staging shorebirds during this critical period in their lifecycle. 
Oil and gas exploration and development is increasing in northern Alaska (NAS 2003), creating the potential for additional impacts on birds of the region. There are many leases and developments on State of Alaska lands west of the Arctic Refuge, including recent exploration activities at Point Thomson on the Refuge's western boundary. There have also been recent offshore lease sales in the Chukchi and Beaufort Seas, including waters adjacent to the Arctic Refuge. Direct impacts of exploration and development activities could include contamination of habitat via spills and disturbance to wildlife. There are also several potential indirect and cumulative effects, including enhancement of nest predator populations (NAS 2003). The northwest portion of the Arctic Refuge is the part of the Refuge nearest existing oil fields and exploration activities. This region appears to be especially important for breeding shorebirds based on the high density of birds observed there (Brown et al. 2007).

In this paper we summarize objectives and results for three studies conducted on shorebirds utilizing the Arctic Refuge coastal plain and adjacent coastal habitats, with particular focus on effects of climate change and human development. Studies include investigation of effects of human infrastructure on nest survival, ecology of post-breeding birds as they aggregate in coastal habitats, and a broader investigation of demographic trends for some of the most imperiled shorebird species that breed in the arctic.

From 2002-2005, we evaluated the relationships between nest survival, predator populations, and proximity to human infrastructure (Liebezeit et al. 2009). This study arose from concern that human food sources and manmade structures used for nesting, denning, or surveillance by predators in the vicinity of developed areas may increase predator populations or cause shifts in their distribution (Day 1998). Factors favoring predators may in turn increase predation of nests or young for ground-nesting birds on the Arctic coastal plain (NAS 2003).

We next turned our attention to the post-breeding period, when shorebirds aggregate in coastal habitats of northern Alaska, including the Arctic Refuge (Taylor et al. 2010). These habitats are believed to be critical for building energy reserves necessary for migration. Deltaic mudflats appear to be especially significant. In addition to direct effects of flooding and erosion, climate change may impact deltaic mudflats by altering the hydrology of north-flowing rivers which form these deltas. Specific objectives of this phase of our work includes: (1) assess abundance, distribution, timing, species composition and habitat requirements of shorebirds staging on coastal areas prior to fall migration; (2) evaluate movement of birds from breeding sites to and among post-breeding sites; (3) determine how food availability (invertebrates) influences shorebird use of coastal habitats; (4) examine physiological responses of birds to prey availability; (5) evaluate effects of predation on invertebrate populations to determine if prey could be a limiting factor for shorebirds; (6) investigate the influence of wind, tides, and fresh-water inflow on mudflat availability in order to project resource availability under future climate scenarios.

The third and most recent phase of our work addresses the need for further demographic data to determine which life history stage of arctic-breeding shorebirds is limiting population growth, i.e., nesting success, juvenile survival, or adult survival. Determining what limits shorebird populations has been identified as critical for developing effective conservation actions (Brown et al. 2001, ASG 2008). Arctic-breeding shorebirds disperse widely during the non-breeding season, making them very difficult to study at that time. Demographic information is therefore best obtained when shorebirds are aggregated on their Arctic breeding grounds. In recognition of this, an international group of shorebird scientists 


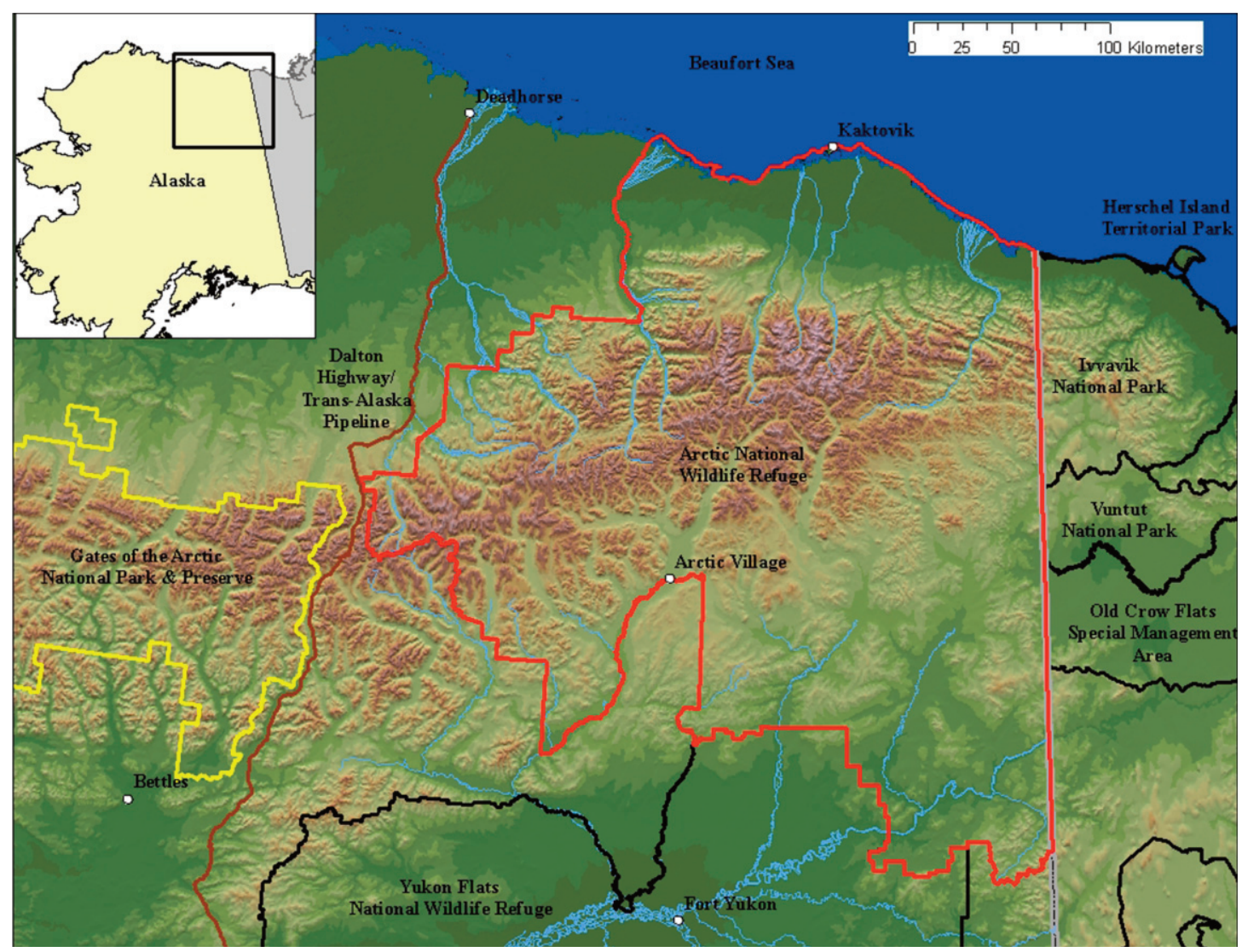

Figure 1. Arctic National Wildlife Refuge, Northeast Alaska and Northwest Canada. Also shown are adjacent conservation lands in Alaska and Canada.

formed the Arctic Shorebird Demographics Network (ASDN) in 2010. Objectives of the ASDN include: (1) evaluate demographic data to assess which specific life history stages are limiting population growth; (2) evaluate environmental factors that can affect shorebirds; (3) enhance understanding of migration routes and overwintering destinations; and (4) compliment other on-going broad-scale monitoring efforts. The Arctic Refuge is participating in the ASDN because of the Refuge's importance for breeding shorebirds and the legacy of avian research and monitoring that the US Fish and Wildlife Service has established here.

\section{Methods}

Study Area.-The coastal plain of the Arctic Refuge extends from the northern foothills of the Brooks Range Mountains to the Beaufort Sea. It is within the Low Arctic region of the Arctic Tundra Biome, and it varies in width from $<10 \mathrm{~km}$ to $>50 \mathrm{~km}$ (Figure 1). Topography of the area is flat to rolling. There are several large rivers that cross the coastal plain as they flow northward from the Brooks Range to the Beaufort Sea. A few of these rivers are of glacial origin, while others are primarily spring fed. Many of the rivers form large deltas where they enter the ocean. The northern boundary of the Refuge is formed by barrier islands, lagoons and coastline. 


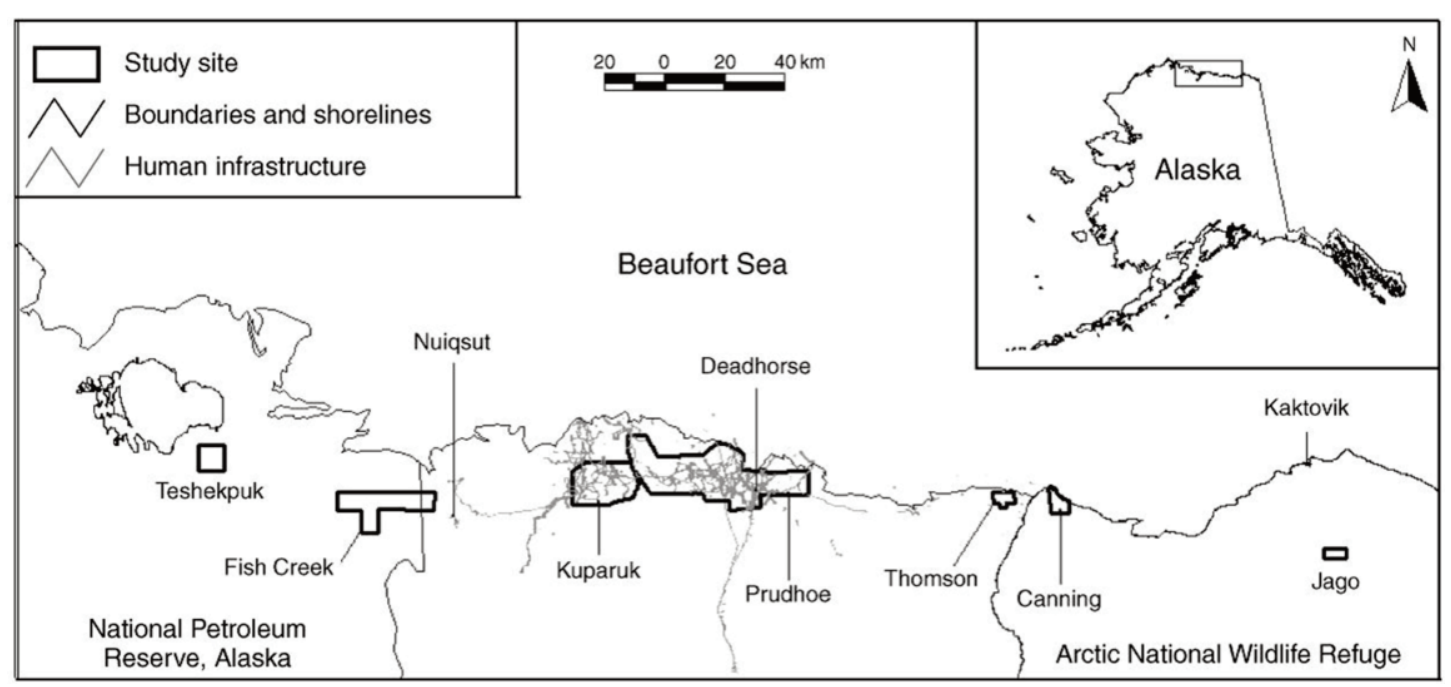

Figure 2. Study sites on the Arctic Coastal Plain of Alaska for investigations of effects of human infrastructure on nest survival of tundra-nesting birds, 2002-2005 (Liebezeit et al. 2009).

The coastal plain is an important breeding area for many avian species, particularly shorebirds, waterfowl and waterbirds. Many of the breeding species depend on the Refuge's coastal habitats as well, particularly during the pre-migratory staging period following fledging of young. The Arctic refuge coastal plain and adjacent habitats are also utilized by avian predators including Rough-legged Hawk (Buteo lagopus), Golden Eagle (Aquila leucocephalus), Merlin (Falco columbarius), Gyrfalcon (Falco rusticolus), Peregrine Falcon ( $F$. peregrinus), Short-eared Owl (Asio flammeus) and Snowy Owl (Nyctea scandiaca).

Influence of Human Development and Predators on Nest Survival of Tundra Birds, Arctic Coastal Plain, Alaska.-This project was a collaboration between non-governmental conservation organizations (Wildlife Conservation Society, Manomet Center for Conservation Sciences), oil companies and their contractors (BP Exploration, Alaska; ConocoPhillips, Alaska; ABR, Inc; LGL, Inc.) and the US Fish and Wildlife Service (Arctic Refuge, Fairbanks Fish and Wildlife Field Office). Studies were conducted during 2002-2005 at multiple sites across the northern Alaska coastal plain, including areas west of the Arctic Refuge. Sites varied in proximity to oil field infrastructure (Figure 2). We investigated nest survival and predator abundance as a function of distance to human infrastructure at each site. Other habitat and environmental variables were evaluated as co-variates, including weather, progression of snow melt, habitat in the vicinity of nests, and microtine abundance. A complete description of methods is found in Liebezeit et al. (2009).

Shorebird Distribution and Abundance at Coastal Staging Sites in the Arctic National Wildlife Refuge.-This work is ongoing and is composed of three phases: (1) evaluation of distribution and habitat use of shorebirds across northern Alaska (Taylor et al. 2010, Taylor et al. in press); (2) documentation of finer-scale distribution of staging shorebirds on the Arctic Refuge; and (3) investigation of food habits of shorebirds in deltaic habitats. Methods have included conducting aerial and ground based surveys of birds using various coastal habitats, color-banding and radio-tagging birds, assessing fat metabolites and stress hormones in blood samples collected from 
birds, and collecting soil core samples to identify and quantify invertebrates.

Arctic Shorebird Demographics Network.-We are conducting coordinated, intensive studies of shorebird demographics at a network of sites across the North American Arctic. Manomet Center for Conservation Sciences, USFWS Migratory Bird Management, and Kansas State University are coordinating this effort. In 2010, partners included the US Fish and Wildlife Service, the Canadian Wildlife Service, academic institutions, and several non-governmental conservation organizations.

The Arctic Refuge Network Site is on the Canning River Delta, which has been identified as an important area for shorebird breeding because of the high density of breeding birds and wetlands found there (Brown et al. 2007). Focal species for monitoring at this site include Semipalmated Sandpiper (Calridris pusilla), Dunlin (C. alpina) and Red-necked Phalarope. For each focal species, we monitor nest success and color band adults. We also record environmental data including weather, snow melt chronology, rate of seasonal habitat drying, and invertebrate, predator and microtine abundance. We will return to Network Sites in 2011 to repeat our sampling and re-sight birds that were marked in 2010. Re-sighting data will be used to calculate annual survival rates and estimate nest-site fidelity. The network will be expanded with additional sites in 2011 . The ASDN has a planned lifespan of $>5$ years.

\section{RESUlTS AND DisCuSSION}

Influence of Human Development and Predators on Nest Survival of Tundra Birds, Arctic Coastal Plain, Alaska.-We found high spatial and temporal variability in several parameters, including nest-success rates and predator abundance. For example, at the Canning River Delta, a site distant from human development located on the Arctic Refuge, we recorded the lowest rate of shorebird nest success for all sites and years in 2002, followed by the high- est success rate in 2003 (Figure 3). We observed similar variability in predator abundance, although predator species such as ravens, gulls, and arctic foxes that are thought to benefit from human activities were generally more common closer to oilfield infrastructure. If proximity to infrastructure does exert a negative effect on nest survival, it may be difficult to detect against this background variability. We did not detect such an effect for shorebirds, although nest survival for Lapland Longspurs (Calcarius lapponicus), a passerine, was lower near infrastructure (Liebezeit et al. 2009).

Predator abundance was not significantly related to nest success in our models, although our methods may not have accurately measured abundance of one of the most important predators, Arctic Fox (Alopex lagopus). Foxes tend to be nocturnal and our predator surveys were conducted diurnally. Further, as a terrestrial mammal, foxes are more difficult to detect than aerial avian predators.

Many of the migratory birds breeding in the Arctic experience multiple stressors in overwintering areas and migratory stopover sites as well as on breeding grounds. Conservation measures implemented in breeding areas will benefit these species, but they must be part of a broader strategy to protect the species throughout their annual ranges. We recommended continuing efforts to reduce predator attractants at new developments in the Arctic, such as limiting access to food wastes and designing infrastructure to reduce artificial nesting, perching, and denning opportunities.

Shorebird Distribution and Abundance at Coastal Staging Sites in the Arctic National Wildlife Refuge.-We identified several highuse areas for post-breeding shorebirds on the Arctic Refuge coast, but there was considerable inter-annual and within-season variability in use of coastal habitats. Factors responsible for this variability may include weather, wind, and water conditions, all of which likely affect 

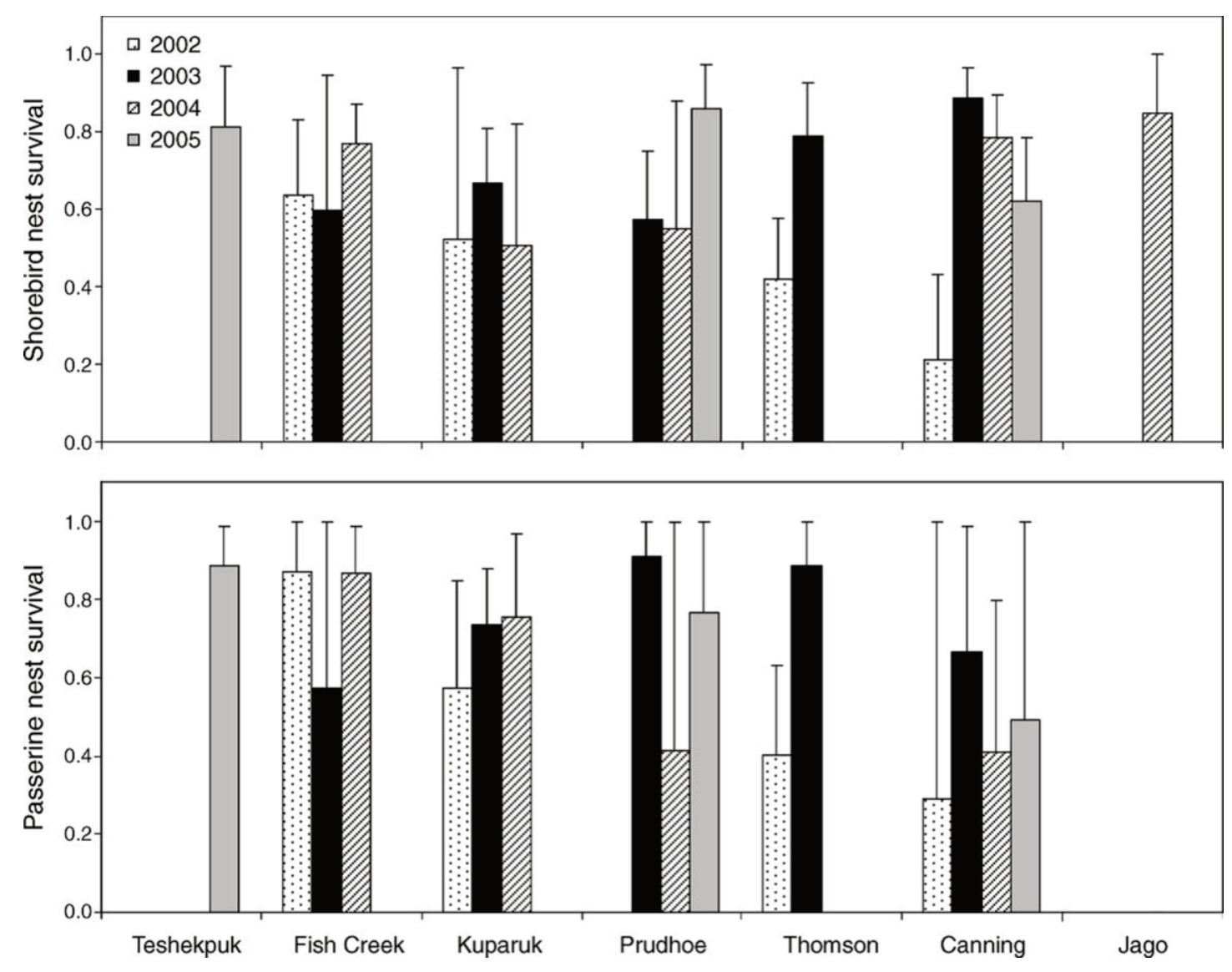

Figure 3. Mean nest survivorship for shorebirds and passerines by study site and year on the Arctic Coastal Plain of Alaska. Error bars indicate half-width 95\% confidence intervals (Liebezeit et al. 2009).

food availability. Abundance and distribution of invertebrates is likely to be a primary determinant of shorebird habitat selection during the post-breeding staging period. We saw evidence of this in 2008, when a wind driven storm surge flooded mud flats during the peak staging period in late July. Numbers of shorebirds in our survey areas dropped off dramatically while water levels were high, but rebounded again when they receded. Preliminary results indicate that not only do these events limit habitat and food availability, but they may cause shifts in invertebrate populations as well. Preliminary results also indicate that no one delta is particularly important for post-breeding shorebirds on the Arctic Refuge.
Rather, birds move among favorable sites in response to changing environmental conditions.

Climate change may affect post-breeding shorebirds by increasing frequency and severity of storm surges. Further, glaciers on the Arctic Refuge have receded in recent decades and the rate of recession is accelerating (Nolan et al. 2005). It is likely that these glaciers will disappear within a few decades (Weller et al. 2007), with potential impacts on shorebird foraging opportunities. Our preliminary results indicate that substrates on glacially fed river deltas differ from those of non-glacial rivers, and this difference has implications for the 
types and numbers of invertebrates found on the deltas. We are currently investigating impacts of these climate-related changes on shorebirds using these staging habitats.

Arctic Shorebird Demographics Network.-We conducted studies at nine Network Sites in 2010. We are now reviewing these data and revising study protocols in preparation for 2011 and beyond. Results of the ASDN will guide management decisions and focus research and conservation efforts toward shorebird recovery at the hemispheric scale. We will assess effects of climate change on shorebird distribution, abundance and survival. We will also monitor contaminant loads in arctic-breeding shorebirds, identify migration routes and overwintering habitats using genetic, stable isotope, and geolocator technologies, and evaluate physiological condition of birds when arriving and departing the Arctic. Our efforts compliment the Program for Regional and International Shorebird Monitoring (PRISM), an on-going, broad-scale, monitoring effort designed to estimate population size and trends for several shorebird species (Skagen et al. 2004, Bart and Earnst 2005). Finally, ASDN participants are evaluating other factors that may affect arctic-nesting shorebirds, such as weather, predator populations, and prey availability (e.g., insects). These data will assist in prediction of, and adaptation to, impacts from current and expected changes in arctic climate and habitats.

\section{Conclusions}

The Arctic is experiencing disproportionately rapid changes associated with accelerating climate change and human development. Effective management of wildlife populations and habitats in the Arctic will require prediction of future conditions, which is complicated by uncertainties associated with climate models (Martin et al. 2009) and cumulative effects of human activities (NAS 2003). Our studies of shorebirds on the Arctic Refuge are a small piece of the larger effort required to evaluate impacts of these changes on arctic birds and their habitats. Long-term monitoring and research, such as that provided by the ASDN, will be especially valuable for developing effective conservation measures to mitigate impacts of future environmental perturbations.

\section{ACKNOWLEDGMENTS}

Funding for these projects came from many sources including: US Fish Wildlife Service, Wildlife Conservation Society, Manomet Center for Conservation Sciences, ConocoPhillips Alaska, Inc., BP Exploration (Alaska) Inc., Angus Gavin Migratory Bird Research Fund, Coastal Marine Institute, Minerals Management Service, US Geological Survey, University of Alaska, Fairbanks, and National Fish and Wildlife Foundation. We thank Joe Liebezeit, Philip Martin, Audrey Taylor, Rick Lanctot, Abby Powell, Steve Zack, Trent McDonald, Rick Johnson, Jon Bart, Brett Sandercock and their respective organizations for collaborating to develop, design and implement these projects. We especially thank our field personnel, too numerous to name, for providing long hours of support under challenging conditions. In particular, we thank Colette Buchholtz, Cashell Villa, Scott Freeman and Ryan Burner for their assistance with extensive logistical planning. We appreciate the Kaktovik Inupiat Corporation kindly permitting us to conduct research on their lands.

\section{Literature Cited}

ACiA. Arctic Climate Impact Assessment. 2005. Arctic climate impact assessment. Cambridge University Press, New York, New York, USA [Online.] Available at http://www.acia.uaf.edu/.

ASG. Alaska Shorebird Group. 2008. Alaska shorebird conservation plan. Version II. Alaska Shorebird Group, Anchorage, Alaska, USA. 
BART, J., AND S. L. EARNST. 2005. Methods for shorebird surveys in the Arctic. Pages 907917 in C. J. Ralph and T. D. Rich (Eds.). Bird Conservation Implementation and Integration in the Americas: Proceedings of the Third International Partners in Flight Conference. 20-24 March 2002. Asilomar, California. Vol. 2. USDA Forest Service General Technical Report PSWGTR-191.

Brown, S., J. Bart, R. B. Lanctot, J. A. Johnson, S. Kendall, D. PAyer, And J. JOHNSON. 2007. Shorebird abundance and distribution on the coastal plain of the Arctic National Wildlife Refuge. Condor 109:1-14.

Brown, S., C. Hickey, B. HARrington, AND R. GILl (Eds.). 2001. United States Shorebird Conservation Plan, 2nd ed. Manomet Center for Conservation Sciences, Manomet, Massachusetts, USA.

DAY, R. H. 1998. Predator population and predation intensity on tundra-nesting birds in relation to human development. Unpublished report to Northern Alaska Ecological Services, US Fish and Wildlife Service, Fairbanks, Alaska, USA, prepared by Alaska Biological Research, Inc., Fairbanks, Alaska, USA.

IPCC. InTERgovernmental PANel ON Climate Change. 2007. Climate Change 2007: Synthesis Report. Contribution of Working Groups I, II and III to the Fourth Assessment Report of the Intergovernmental Panel on Climate Change. In R. K. Pachauri and A. Reisinger (Eds.). IPCC, Geneva, Switzerland.

Kendall, S. J. 2005. Surveys of breeding birds on barrier islands in the Arctic National Wildlife Refuge, 2003-2004. Unpublished Report, US Fish and Wildlife Service, Arctic National Wildlife Refuge, Fairbanks, Alaska, USA.

Liebezeit, J. R., S. J. Kendall, S. Brown, C. B. Johnson, P. Martin, T. L. Mcdonald, D. C. Payer, C. L. Rea, B. Streever, A. M. Wildman, AND S. ZACK. 2009. Influence of human development and predators on nest survival of tundra birds, Arctic
Coastal Plain, Alaska. Ecological Applications 19:1628-1644.

Martin, P. D., J. L. Jenkins, F. J. Adams, M. T. Jorgenson, A. C. MAtz, D. C. PAYer, P. E. Reynolds, A. C. Tidwell, And J. R. ZELENAK. 2009. Wildlife response to environmental Arctic change: Predicting future habitats of Arctic Alaska. Report of the Wildlife Response to Environmental Arctic Change (WildREACH): Predicting Future Habitats of Arctic Alaska Workshop, 17-18 November 2008. US Fish and Wildlife Service, Fairbanks, Alaska, USA.

NAS. NATional ACADEmy Of Sciences. 2003. Cumulative Environmental Effects of Oil and Gas Activities on Alaska's North Slope. National Academies Press, Washington, DC, USA.

Nolan, M., A. Arendt, B. Rabus, and L. HINZMAN. 2005. Volume change of McCall Glacier, Arctic Alaska, from 1956 to 2003. Annals of Glaciology. 42:409-416.

NSDiC. National Snow and Ice Data CenTER. 2010. NSIDC homepage. [Online.] Available at http://www.nsidc.org/news/ press/20101004_minimumpr.html.

RAMSAR. 1999. Strategic framework and guidelines for the future development of the list of wetlands of international importance. Adopted by Conference of Contracting Parties 7, 1999. [Online.] Available at http://www.ramsar.org/cda/en/ramsardocuments-guidelines-strategic-frameworkand/main/ramsar/1-31-105\%5E20823_ 4000_0.

SkAgen, S. K., J. BART, B. ANdres, S. Brown, G. Donaldson, B. HARrington, V. JohnSTON, S. L. JONES, AND R. I. G. MORRISON. 2004. Monitoring the shorebirds of North America: Towards a unified approach. Wader Study Group Bulletin 100:102-104.

TAYlor, A. R., R. B. LANCTOT, A. N. POWELL, F. Huettmann, D. A. Nigro, and S. J. Kendall. 2010. Distribution and community characteristics of staging shorebirds on the northern coast of Alaska. Arctic 63:461467. 
TAYLOR, A. R., R. B. LANCTOT, A. N. POWELL, S. J. KendALl, AND D. A. NigRo. Residence time and movements of postbreeding shorebirds on the northern coast of Alaska. In press.

US Fish AND WILDLIFE SERVICE. 2008. Birds of conservation concern 2008. United States Department of Interior, US Fish and Wildlife Service, Division of Migratory Bird Management, Arlington, Virginia. [Online.] Available at http://www.fws.gov/ migratorybirds/.

Weller G., M. Nolan, G. Wendler, C. BenSON, K. ECHELMEYER AND N. UNTERSTEINER. 2007. Fifty years of McCall Glacier research: From the International Geophysical Year 1957-58 to the International Polar Year 2007-08. Arctic 60:101110.

WSHRN. Western Hemisphere Shorebird RESERVE NETWORK. 2006. Western Hemisphere Shorebird Reserve Network selection criteria. [Online.] Available at http://www.whsrn.org/selection-criteria. 